\title{
Adaptation and Mitigation Model for People to Restore Their Ecosystem from Flood in Semarang, Indonesia
}

\author{
Muzakar Isa ${ }^{1}$, FX. Sugiyanto ${ }^{2}$, Indah Susilowati ${ }^{2}$ \\ ${ }^{1}$ Faculty of Economics, Muhammadiyah University of Surakarta \\ Jalan A. Yani Pabelan Kartasura Surakarta 57102, Indonesia \\ 2 Faculty of Economics and Business, Diponegoro University. \\ Jalan Prof. Sudarto, Kampus Tembalang, Semarang 50275, Indonesia \\ Correspondence e-mail: muzakarisa@gmail.com
}

Received: July 2015; Accepted: October 2015

\section{Abstract}

The northern coast of Central Java province is considered as the critical area of flood path. Semarang as capital city of this province with its junction area of Kendal and Demak always suffering from flood due to rain and or high tide seawater. It is realised that infrastructures' capacity for flood control, awareness of people and other multi-factors are significantly contributed on the flood problem in these area. Mixed-methods of quantitative and qualitative are employed to analyze the data. The study found that there was a decline in quality of - people's life, environment and its ecosystem. Awareness and responsiveness of people and also the other stakeholders are not progressive to overcome the problem of flood. This study is trying to contribute in outlining a model of adaptation and mitigation for the people to restore their ecosystem from the perspective of economist.

Keywords: flood, climate-change, adaptation, mitigation

JEL Classification: Q51, Q54

\section{Model Adaptasi dan Mitigasi untuk Masyarakat Dalam Pemulihan Ekosistem Akibat Banjir di Semarang, Indonesia}

\begin{abstract}
Abstrak
Pantai Utara di Provinsi Jawa Tengah dianggap sebagai daerah jalur kritis banjir. Semarang sebagai ibu kota Provinsi ini merupakan daerah persimpangan jalur Kendal dan Demak yang selalu mengalami banjir karena hujan dan atau pasang air laut. Disadari bahwa kapasitas infrastruktur untuk pengendalian banjir, kesadaran orang dan berbagai faktor lain sangat berperan bsar dalam persoalan banjir di daerah ini. Untuk menganalisis data dipergunakan metode campuran kuantitatif dan kualitatif. Hasil penelitian menunjukkan bahwa ada penurunan kualitas hidup masyarakat, lingkungan, dan ekosistem. Kesadaran dan respon dari orang-orang dan juga para pemangku kepentingan lain yang tidak progresif untuk mengatasi masalah banjir. Penelitian ini sedang mencoba untuk berkontribusi dalam menguraikan model adaptasi dan mitigasi bagi masyarakat untuk memulihkan ekosistem mereka dari sudut pandang ekonom.
\end{abstract}

Kata kunci: banjir, perubahan iklim, adaptasi, mitigasi

Klasifikasi JEL: Q51, Q54

\section{Introduction}

Indonesia is the six ranks in the world for flood risk and dangerous. On 1815 and 2013 year, Indonesia had flood experience for 5.233 times or $38.99 \%$ from the total of nature disaster in Indonesia (BNPB, 2014). Semarang is the capital city of Central Java province, has high fre- quency in flood. It lies at the northern coast of central java, its location is bordering with Kendal and Demak, both of them are the dangerous and risk flood area.

The main sources of flood water at Semarang city - Indonesia is raining and river, The high rain frequency and long duration is 


\section{Jurnal Ekonomi Pembangunan, 16 (2), Desember 2015, 166-173}

caused river cannot receive rain water, so that, flood happened. Flood from the river water, besides influenced by rain water it also caused by narrowing river stream, damage dam, and river silting. Semarang position that lies in coastal area, often caused the river water can't flow to the ocean smoothly because the increasing of ocean water stream made a wide and high flood.

Flood at Semarang on 2009 - 2013 had very big impact, mainly 81 people to be the sacrifices/victims, 61,192 people migrate, 45.686 Ha destroyed area, $139 \mathrm{~km}$ road broken and 1.782 houses had heavy broken (BNPB, 2014). Besides that, Harwitasari (2009) to add flood also gave impact to (1) Human resources loosing that can be renewed or improved (2) Areas damaged that are functioned as recreation park, and tourism, (3) Value and cultural sources loosing that can't be valued, and (4) Water and land quality decreasing for agriculture and fishery.

Many efforts have been done by the government and society of Semarang city for reducing flood impact through adaptation and mitigation flood. Swart and Frank (2007) and Thomas et al. (2003) explaining adaptation and mitigation as two concepts that is aimed for reducing flood risk. Flood mitigation is defined as the effort for reducing the flood impact, such as: the amount of dead victims, amount of destroyed things and lost things. Flood adaptation is defined as the effort of natural and human being system Adaptation as the response towards the risk stimulus, mainly: the vulnerable that consists of: (exposure), (sensivity), and (adaptive capacity) aspects. Swart and Frank, (2007) explained that the flood impact as the concept of flood risk as function from danger, and the vulnerable, while the vulnerable factor as the function of exposure, sensivity, and adaptive capacity.

Flood adaptation and mitigation can be done through (1) Structural and non-structural (Changzhi Li, et al., 2012; Wedawatta and Ingirige, 2012; Lawson et al. 2011)), (2) Identification and reducing the vulnerable from physical, environment, social and economic aspects (Moser, et al., 2010; Florina, 2007; Chaliha, 2012, Balica, et al, 2012), (3) vulnerable identi- fication of exsposure sensivity, and adaptive capacity aspects. (Smit and Wandel, 2006; Turner et al., 2003; and Brenkert and Malone, 2005), (4) Improvement and development program through the increasing of education level, income, insurance and poverty reducing (Chan, 1997; and Eziyi, 2011), (5) The increasing of society capacity (Yuniartanti, 2012; Hardoyo, 2011; Maharani, 2012), (6) the increasing of society participation (Olofsson, 2007; Fordham, 1998; Quarantelli, 2005), and (7) The increasing of society recognizing and capacity (Suryanti et al., 2010; and Zein, 2010).

Flood adaptation and mitigation at Semarang city had done a lot but the flood impact keeps still high. It is regarded because flood model of adaptation and mitigation has not optimum. It is influenced by (1) the model of adaptation and mitigation that have not optimum; (2) there are still many people/society that regards flood as "Acts of God" and also as external aspect beyond human being ability. As acts of God, Flood is regarded as punishment, warning or examination from GOD, (3) Society viewed flood as external aspect beyond people ability, so that, it is needed technology innovation to reduce flood risk. Therefore, local wisdom in reducing flood is often ignored.

The research aims are: (1) to identify flood impact at Semarang city - Central Java - Indonesia, (2) to identify the society and government awareness and response towards flood at Semarang city - Central Java - Indonesia, and (3) to formulate the model of flood adaptation and mitigation at Semarang city - Central Java Indonesia.

\section{Research Method}

Research Population is societies that have experienced of flood at Semarang city - Central Java - Indonesia in the last three years. Sample choosing is the key persons by using purposive sampling like which have been applicated by Susilowati (2013). Key person is chosen by using snowball sampling, mainly taking sample that is choosen at the beginning is one respondent, then, it is completed by other respondents, who are viewed know and able to complete the exist data until reach up the saturation point. It means that; when the answer is taken have 


\section{Jurnal Ekonomi Pembangunan, 16 (2), Desember 2015, 166-173}

similar experience, so informant taking will be stopped.

This research used mixed method approach. Data gathering used interview and Focus Group Discussion (FGD). Interview is conducted by asking straightly to respondent by using questionnaire. FGD is used for collecting information, attitude, opinion, and respondents group decision. Analysis descriptive quantitative is used to describe the flood impacts, awareness, and response from society and government towards flood at Semarang city - Central Java - Indonesia. Then, to arrange the model of flood adaptation and mitigation at Semarang city - Central Java - Indonesia, by using content analysis, that is; to analyse the meaning of FGD results and interview. In this analysis is also explained how is the participants of stakeholder in reducing flood risk, both before flood (preventive), on disaster (emergency response) or after the flood (recovery and reconstruction).

\section{Results and Discussion}

Based on the city planning of Semarang city in 2011-2031 year is mentioned that flood area risk of Semarang city is spread out in ten districts, Those are: North Semarang, West Semarang, East Semarang, Tugu, Candisari, Gunungpati, Gayamsari, Pedurungan, Tembalang, and Genuk. Flood frequency, pool width and pool length in general much happened at Gayamsari, Peduruangan and Genuk districts. On the last three years, the society of Semarang city has got flood experience among 1 - 4 times every year. Society that has flood experience 2 3 times in a year is $69,40 \%$, Society that has flood experience 3 times in a year is $20,70 \%$, and Society that has flood experience 1 time in a year is $9,90 \%$. The pool high of flood water can be classified to be 3 ; those are: less than 0.5 meter, between 0.5-1 meter and more than 1 meter. Societies that have flood experience with high pool less than 0.5 meter is $48,60 \%$, followed high pool between $0.5-1$ meters is $44.10 \%$

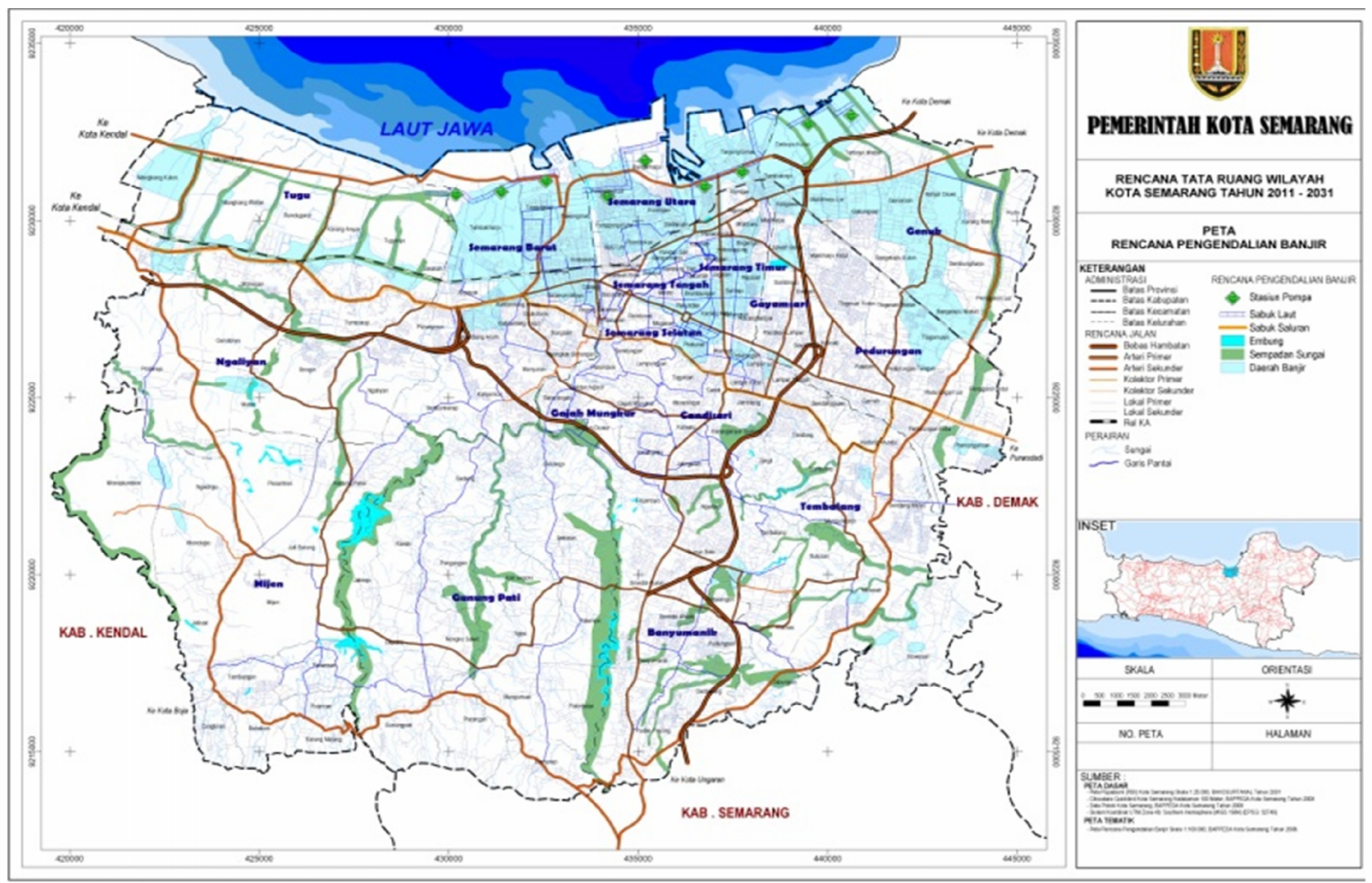

Figure 1. Disaster Risk Mapping at Semarang City - Central Java - Indonesia

Source: RTRW at Semarang city between 2011-2013 year. 


\section{Jurnal Ekonomi Pembangunan, 16 (2), Desember 2015, 166-173}

and high pool more than 1 meter is $7,20 \%$. Then, the lengths of flood pools are variants between less than one day until more than one week. The most length of pool between 1 day untill 1 week, that is $91.00 \%$, followed more than one week and less than one day is $4.50 \%$ each.

Flood at Semarang city has impact towards the decreasing of life society quality, such as: health, refugees, loosing job, and migrate. In one time flood, society that needs medicine in 2 - 3 times is around $65.8 \%$, followed one time need medicine is around $24.30 \%$ and need medicine more than 3 times is around $9.90 \%$. Every times flood happened the society that need to refuge is around $38.70 \%$. They refuge at Masjid, school, and dam that are used as flood refuge. Societies that have lost their job is $2.70 \%$, generally they work in informal sector. Society that doing migrate to the other area is $33.30 \%$.

Flood at Semarang city also gave impact in reducing environment quality. When flood happened, there was $45.90 \%$ society has difficulty in getting clean water. For getting clean water in one time flood, every family should pay between IDR 50,000 and IDR 500,000. That is much money.

The awareness of Semarang city society towards flood is still low. Society that has been doing information access from electronic, printing media and internet are not so much. Based on the interview result was explained that around $59,5 \%$ society is rarely to access flood information, while society that is often access flood information is around 13,5\% and society that is always access flood information is only $8.1 \%$. Then, the society participation on insurance is also still small, is around $20.7 \%$. Insurance that they followed is mostly in health and labour.

Semarang city government does not serious in handling flood problem. That problem has linked with government effort in handling river condition, dam, and water door, evacuation path route, houses distance to evacuate location, the existence of flood risk road mapping, flood emergency service, early warning, flood socialization and training. Semarang city society said that river condition, dam, and water door unmaintenance is only about $52,30 \%$, and then followed is about $41,40 \%$ society that has stated unmaintenance and around $6.30 \%$ society said in good maintenance. Then for flood victims/sacrifices evacuation path route, is $79.3 \%$ society answered that the condition is damaged and $20.7 \%$ society explained that the condition is good. The distance from home to location of flood victims' evacuation is variants. The evacuate location distance that is more than $1 \mathrm{~km}$ is $11,7 \%$, the distance between $100 \mathrm{~m}$ until $1 \mathrm{~km}$ is $67,7 \%$ and distance that less from $100 \mathrm{~m}$ is $18.00 \%$.

The government of Semarang city has not done maximally for handling the flood. It is around $82.00 \%$ society said that the government of Semarang city did not do flood emergency service. Flood risk mapping at Semarang city did not socialize until grass root society level. That mapping only lies at village, district, and BPBD offices. It is around $66.70 \%$ society did not know about flood risk mapping existence at their own area. For kinds of flood early warning, is done by using microphone and kentongan or hitting electricity stake. This warning did not understand by the society well, there is around $78.40 \%$ society explained that there is no early warning at the time of flood happened in their area.

Flood training and socialization are still limited and not so much done by the government of Semarang city. Activity like the way to overcome flood, emergency response, refuge and general kitchen have not understood by society. This is strengthen by the society attitude $97.30 \%$ explained that there is no training flood managing and $95.50 \%$ society that explained there is no flood socialization by the government and the other institutions.

Flood adaptation and mitigation activity that is conducted at Semarang city usually adhocly and unplanning in systematically and continually. The kinds of flood adaptation is conducted by Semarang city society are: (1) to make higher environment path, (2) to make higher houses terraces in their own houses, (3) to make dam at their own houses terrace for blocking water to enter their houses, (4) to improve water door, and (5) to improve the damaged river dam in village area. 
Avalaible online at http://journals.ums.ac.id

Jurnal Ekonomi Pembangunan, 16 (2), Desember 2015, 166-173

Table 1. Stakeholders Role in Flood Managing at Semarang City

\begin{tabular}{llrrr}
\hline \multicolumn{1}{c}{ The Conducting of Flood Managing } & \multicolumn{3}{c}{ Stakeholders role } \\
No & $\mathrm{A}$ & $\mathrm{B}$ & $\mathrm{C}$ & $\mathrm{G}$ \\
\hline Before - Flood & 5.4 & 5.3 & 6.2 & 6.9 \\
1. Situation No Flood & 5.3 & 5.4 & 6.5 & 6.8 \\
2. Situation Flood Potential & 6.3 & 6.5 & 7.5 & 7.7 \\
Emergency Response & & & & \\
After Flood & 5.3 & 6.2 & 7.2 & 7.6 \\
1. Rehabilitation & 5.2 & 5.7 & 7.2 & 7.3 \\
2. Reconstruction & 5.6 & 5.8 & 6.8 & 7.3 \\
Average Totally & \multicolumn{3}{c}{}
\end{tabular}

Source: Data Printer (2015)

Flood mitigation at Semarang city for this time being is done through structural, nonstructural activity, and society participation. Structural activity that have been done, such as: (1) Dam improvement, drainage, and river, (2) to block the source of flood water by using sand that entering to sacks, and (3) to make drainage system for wasting disposal. Nonstructural that have been done, such as; (1) Evacuation training for checking society preparation, $\mathrm{BPBD}$, and evacuation equipment, also the refuge/shelter preparation and the accomplishment, (2) to set up flood shelter and general kitchen for flood victims, (3) to provide logistic that is needed for activity and effort for emergency response, (4) to prepare district map of flood risk that is completed by route for refugees, location the refuge and shelter, and (5) to form the links of intra institutions/sectors and NGO that gave closed attention and care about disaster/flood, also mass media both electronic or printing (TV and Radio stations) for conducting campaign to take care of disaster/flood to all of societies including the delivery of flood information.

Flood mitigation through society role activity, those are: (1) throwing the rubbish at the right place and not throw away in river, the stream and drainage system; (2) following training and socialization flood mitigation effort, and (3) conducting cooperation and working together in cleaning drainage system in their own environment.

To know how far the stakeholders role in conducting flood managing, both pre flood, emergency response, after flood is conducted evaluation by giving value academic participation (A), Business (B), Community (C) and Government (G) by giving score between 1-10. stakeholders role in flood managing at Semarang city is variant. Government is the most dominate role in flood managing, followed by society, businessmen/women and the last is university.

BPBD as government institution that carry out flood adaptation and mitigation as new institution that is formed based on UU No. 24, 2007 year, about disaster overcoming. So that, based on that regulation, reducing activity of flood risk at national level is conducted by Disaster Overcoming National Institution/ Badan Nasional Penanggulangan Bencana (BNPB), and for province and districts level is conducted by District Disaster Overcoming Institution/Badan Penanggulangan Bencana Daerah (BPBD).

One of the problems of flood adaptation and mitigation at Semarang city is model of flood adaptation and mitigation that has not optimum, in which that activity is only conducted by BPBD (government) whereas university, businessmen/women and society have very important role, but never been involved in that case actively. For optimizing the flood adaptation and mitigation is proposed model that can be accommodated by all the stakeholders. 
Jurnal Ekonomi Pembangunan, 16 (2), Desember 2015, 166-173

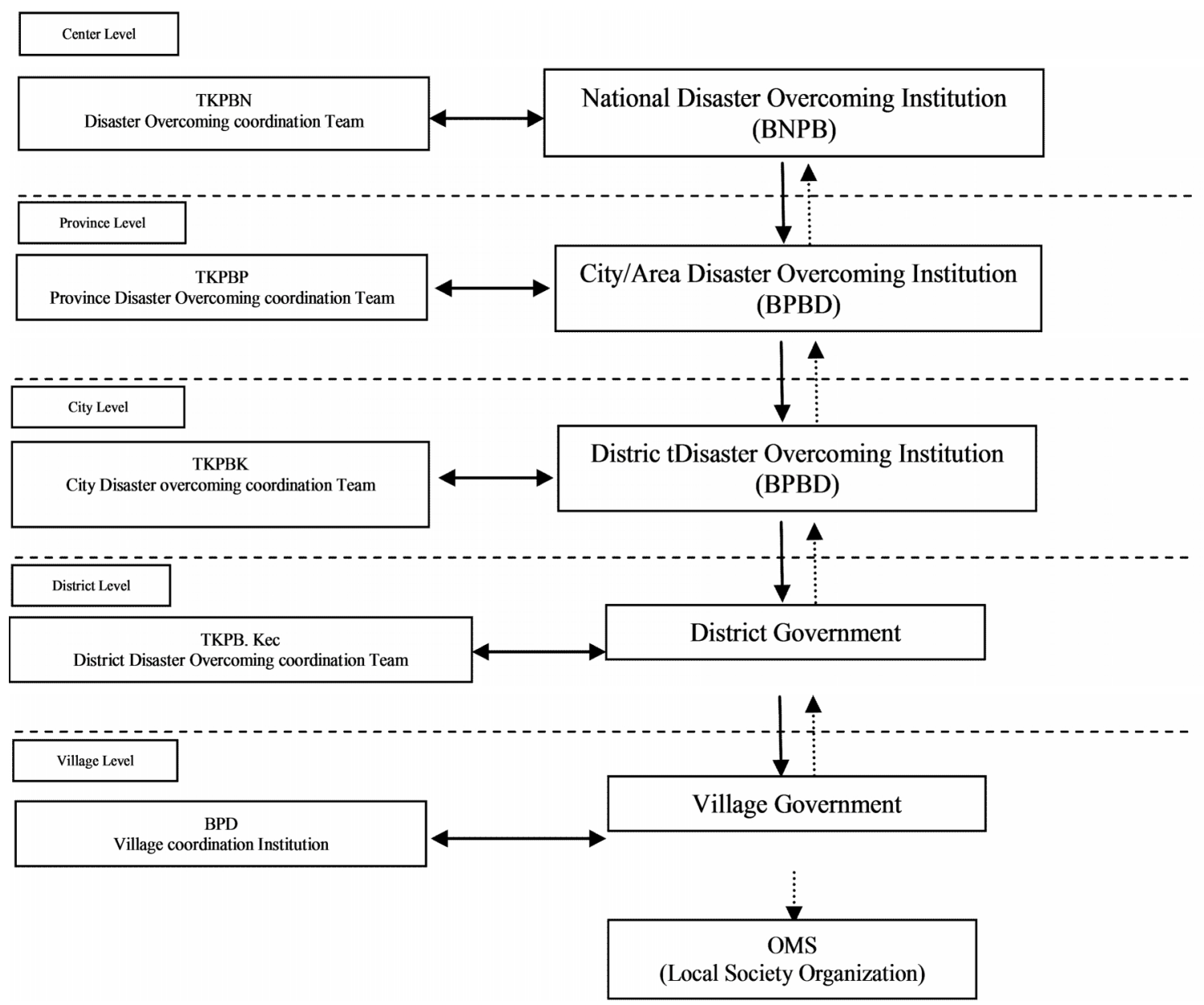

Figure 2. Flood Adaptation and Mitigation Model

\section{Conclusions}

The study result found that there was a decline in quality of - people's life, environment and its ecosystem. Awareness and responsiveness of people and also the other stakeholders are not progressive to overcome the problem of flood. Most of efforts to get rid of flood are in ad-hoc system and no grand-design in the perspective of ecosystem-based. This study is trying to contribute in outlining a model of adaptation and mitigation for the people to restore their ecosystem from the perspective of economist. Of course, it needs further research and trials to get a suitable model.

\section{References}

Badan Nasional Penanggulangan Bencana (BNPB). 2014. Data Informasi Bencana Indonesia. Jakarta: BNPB,

Balica, S. F. et.al. 2012. A flood vulnerability index for coastal cities and its use in assessing climate change impacts. Nat Hazards (2012) 64:73-105. DOI 10.1007/ s11069-012-0234-1

Benkert, A. and Malone, E. 2005. Modeling vulnerability and resilience to climate change: a case study of India and Indian states, Climatic Change, Vol. 72, pp. 57102. 


\section{Jurnal Ekonomi Pembangunan, 16 (2), Desember 2015, 166-173}

Chaliha, Swati. 2012. Climate variability and farmer's vulnerability in a flood-prone district of Assam. International Journal of Climate Change Strategies and Management Vol. 4 No. 2, 2012 pp. 179-200

Chan, Ngai Weng. 1997. Increasing flood risk in Malaysia: causes and solutions. Disaster Prevention and Management, Volume 6 . Number $2 \cdot 1997 \cdot \mathrm{pp}$. 72-86

Changzhi Li, Shuaijie Li, and Xiaotao Cheng. 2012. Flood Risk Assessment in Fujian Province, China. Journal of Disaster Research Vol.7 No.5, 2012

Creswell, John W., Clark, Vicki L. Plano. 2007. Designing and Conducting Mixed Methos Research. America. University of $\mathrm{Ne}$ braska-Lincoln.

Eziyi, Offia Ibem, 2011. Challenges of disaster vulnerability reduction in Lagos Megacity Area, Nigeria Disaster Prevention and Management, Vol. 20 No. 1, 2011pp. 27-40

Florina, Balica Stefania. 2007. Development and Application of Flood Vulnerability Indices for Various Spatial Scales, Master of Science Thesis, UNESCO-IHE Institute for Water Education, Delft, the Netherlands.

Fordham, M. 2007. Gendering vulnerability analysis: towards a more nuanced approach, in Bankoff, G., Frerks, G. and Hilhorst, D. (Eds), Mapping Vulnerability: Disasters, Development and People, Earthscan, Sterling, VA, pp. 174-82.

Fordham, M. H. 1998. 'Making women visible in disasters: problematizing the private domain'. Disasters, Vol. 22, No. 2, pp. 126143.

Hardoyo, Surito., Muh Aris Marfai, Novi Maulida Ni'mah, Rizki Yustiana Mukti, Qori'atu Zahro, Anisa Halim, 2011. Strategi adaptasi masyarakat dalam menghadapi bencana banjir Pasang air laut di Kota Pekalongan, laporan penelitian, Magister Perencanaan dan Pengelolaan Pesisir dan Daerah Aliran Sungai (MPPDAS), Program S-2 Geografi, Fakultas Geografi Universitas Gadjah Mada.
Harwitasari, Dian. 2009. Adaptation Responses to Tidal Flooding In Semarang, Indonesia, Thesis, IHS Erasmus, Rotterdam

Lawson, Z. J., J. W. Gaeta, and S. R. Carpenter. 2011. Coarse woody habitat, lakeshore residential development, and largemouth bass nesting behavior. North American Journal of Fisheries Management 31:666670.

Maharani, Sholawatul. 2012. Pola adaptasi penduduk dan arahan mitigasi pada daerah banjir lahar hujan Di bantaran sungai code (Kasus Sungai Code, antara Arteri Utara hingga Jembatan Kewek). Jurnal Bumi Indonesia. Volume 1, Nomor 3, Tahun 2012.

Moser, C., Andrew Norton, Alfredo Stein, Sophia Georgieva, 2010. Pro-Poor Adaptation to Climate Change in Urban Centers: Case Studies of Vulnerability and Resilience in Kenya and Nicaragua, The World Bank: Sustainable Development Network - Social Development Department, Report No. 54947-GLB, June 2010.

Olofsson, A. 2007. The preparedness of local authorities for crisis communication with people who have foreign backgrounds the case of Sweden, International Journal of Mass Emergencies and Disaster, Vol. 25, No. 2, pp. 145-173.

Quarantelli, E. L. 2005. A Social Science Research Agenda For The Disasters Of The 21st Century: Theoretical, Methodological And Empirical Issues And Their Professional Implementation, in Perry, R. W., and Quarantelli, E. L. (eds.), What is a Disaster? New Answers to Old Questions, Xlibris Corporation, Philadelphia, pp. 325-396.

Smit, B. and Wandel, J. 2006. Adaptation, adaptive capacity and vulnerability, Global Environmental Change, Vol. 16, pp. 282-92.

Suryanti, E.D., Rahayu, L., dan Retnowati, A. 2010. Motivasi dan Partisipasi Masyarakat dalam Upaya Pengurangan Multirisiko Bencana di Kawasan Kepesisiran Parangtritis dalam Penaksiran Multi- 
Jurnal Ekonomi Pembangunan, 16 (2), Desember 2015, 166-173

risiko Bencana di Wilayah Kepesisiran Parangtritis, Yogyakarta, PSBA UGM.

Susilowati, Indah. 2013. Prospek pengelolaan sumber daya perikanan Berbasis ekosistem: studi empiris di karimunjawa. Jurnal Ekonomi Pembangunan Volume 14, Nomor 1, Juni 2013, hlm. 16-37.

Swart Rob dan Frank Raes, 2007. Making integration of adaptation and mitigation work: mainstreaming into sustainable development policies? CLIMATE POLICY 7 (2007) 288-303.

Thomas J. Wilbanks, Sally M. Kane, Paul N. Leiby, Robert D. Perlack, Chad Settle , Jason F. Shogren \& Joel B. Smith. 2003 Possible Responses to Global Climate Change: Integrating Mitigation and Adaptation, Environment: Science and Policy for Sustainable Development, 45:5, 28-38.

Turner, B. L., R.E. Kasperson, P.A. Matson, J.J. McCarthy, R.W. Corell, L. Christensen, N. Eckley, J.X. Kasperson, A. Luers, M.L. Martello, C. Polsky, A. Pulsipher and A.
Schiller (2003) "A framework for vulnerability analysis in sustainability science", Proceedings of the National Academy of Sciences, 100(14): 8074-8079.

Turner, B.A. and Pedgeon, N.F. 1997, ManMade Disasters, 2nd ed., ButterworthHeinemann, Oxford.

Wedawatta, Gayan dan Ingirige, Bingunath. 2012. Resilience and adaptation of small and medium-sized enterprises to flood risk, Disaster Prevention and Management Vol. 21 No. 4, 2012 pp. 474-488.

Yuniartanti, Rizki Kirana. 2012. Migrasi Vs Adaptasi Sebagai Solusi Dampak Perubahan Iklim Di Kawasan Perkotaan, Prosiding Temu Ilmiah IPLBI 2012.

Zein, M. 2010. A Community Based Approach to Flood Hazard and Vulnerability Assessment in Flood Prone Area: A Case Study in Kelurahan Sewu, Surakarta City, Indonesia, Thesis, ITC, The Netherland. Natural disasters and economic development. 